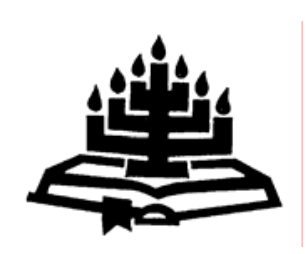

\title{
The reformed confessions: embarrassment or blessing to a missionary church?
}

\author{
J.J. Fritz Krüger \\ School of Ecclesiastical Sciences (Missiology) \\ Potchefstroom Campus \\ North-West University \\ POTCHEFSTROOM \\ E-mail: fritzkruger@telkomsa.net
}

\begin{abstract}
The reformed confessions: embarrassment or blessing to a missionary church?
\end{abstract}

The historic reformed confessions are sometimes blamed for the apparent lack of missionary zeal among churches of the RCSA, and called an embarrassment to the church. This article investigates these allegations and attempts a missionary reading of the confessions. Because of the specific focus of the confessions, they should not be expected to give guidance on the whole life of the church. However, careful reading of the creeds does offer a surprisingly abundant missionary harvest. They offer both the foundations and the limits for mission, and in defining the identity of Christians, also define the missionary identity of the church. As the community of fellowship with Christ, the church is both a unique instrument in the "missio Dei" and the end objective of mission (mission as church planting). Creeds offer beautiful expositions of the loving, fellowshipseeking heart of God who has not given up on fallen humanity, but who continues to call people to fellowship with Him in his self-revelation in creation, Scripture and the incarnation of the Son. Surprisingly, it is the Canons of Dordt (2.5) which offers the only explicit call to mission in the three creeds!

\section{Opsomming}

Die gereformeerde belydenisse: verleentheid of seën vir 'n missionêre kerk?

Die histories gereformeerde belydenisskrifte kry soms die skuld vir die klaarblyklike gebrek aan sendingywer by kerke van die GKSA, en word selfs 'n verleentheid vir die kerke genoem. Hierdie artikel ondersoek die uitsprake en onderneem 'n missionêre 
lees van die belydenisskrifte. As gevolg van die spesifieke fokus van die belydenisskrifte, moet daar nie van hulle verwag word om leiding te gee op alle terreine van die kerklike lewe nie. Nogtans lewer 'n versigtige lees van die belydenisskrifte 'n verbasend groot missionêre oes op. Hulle bied sowel die fondamente as die grense van sending, en deur die identiteit van Christene te definieer, definieer hulle ook die missionêre identiteit van die kerk. As gemeenskap van mense wat in gemeenskap met Christus lewe, is die kerk sowel 'n unieke instrument in die "missio Dei" asook die doel van sending (sending as kerkplanting). Belydenisskrifte bied wonderlike uiteensettings van die liefdevolle, gemeenskapsoekende hart van God wat nie opgegee het met die gevalle mensdom nie, maar wat voortgaan om mense tot gemeenskap met Hom te roep deur sy selfopenbaring in die skepping, in die Skrif en in die inkarnasie van die Seun. Verbasend genoeg is dit juis die Dordtse Leerreëls (2.5) wat die enigste eksplisiete oproep tot sending in al drie belydenisskrifte laat hoor!

\section{Introduction}

During the past few years, we have seen a growing discussion within the RCSA ${ }^{1}$ on the missionary calling of our churches - or rather: the perceived lack of missionary consciousness and activity. ${ }^{2}$ In discussions, some people have tried to blame this on the doctrinal teaching of the church, more specifically on the reformed confessions, and specifically the doctrine of divine predestination (cf. Van der Merwe, 1960:2). In their opinion, the confessions contain nothing that would inspire members or congregations to participate in mission, neither do they contribute to the formation of a missionary RCSA. In a sense, the confessions have therefore become an embarrassment to the church, rather than a blessing.

Haak (1999:61-62), speaking with obvious piety about the reformers and the reformed confessions, defends the confessions against these claims by conceding that the confessions do not present a missionary and inviting ecclesiology, but rather a defensive and conservative one, reflecting a church concerned only with herself

1 The abbreviation RCSA (Reformed Churches in South Africa) is the English equivalent of the Afrikaans GKSA (Gereformeerde Kerke in Suid Afrika).

2 Since 2005, annual mission conferences, organised by congregations of the RCSA and the Faculty of Theology of the North-West University, present a forum for discussion of these matters. The viewpoints referred to here were expressed during these conferences. 
and her own survival. However, this is the result of the context within which the confessions originated, and of the fact that no single confession can be absolutely comprehensive in its following of Scripture. The limitations of the reformed confessions are therefore understandable.

In speaking of the missionary calling of reformed churches, the question is whether the confessions really deserve to be the embarrassment they are to some. Do they deserve to take the blame for the perceived lack of missionary zeal of our churches? The following remarks will attempt an answer to this question, by offering a missionary reading of the confessions. Due to constraints of space, only a relatively small selection out of the total wealth of the confessions can be offered.

\section{The function of confessions}

According to Schaff (1877:4), a creed is a confession for public use - which in itself renders the document one of expression and outward communication of the doctrine of the church (cf. Schulze, $1991: 2,3)$. The very possession of confessions should already stimulate missionary activity: they are not intended to be treasured possessions carefully locked away in the vaults of the church, only put on view at certain solemn occasions and then polished before they are once again consigned to the underground vaults of the treasury. They are intended to be printed on banners and hung above the doors of our churches - on the outside, inviting in; they are intended to be printed and handed out as summaries of our faith, inviting careful thought and consideration; they are intended to be hung out like flags, commanding attention; they are intended to be raised like banners in front of a marching crowd, urging them on to enter the world in the name of Jesus with his message of reconciliation and peace. In this sense, then, there is little difference between an apologetic and a missionary function of the confessions.

In its Greek form, the word sumbol on means a mark, badge or watchword. In other words, it functions as an indication of identity, especially in the military sense (cf. the church as ecclesia militans): Which army is this? The answer: the army of Christ! Such a mark of identity or military banner always has two functions: for those who belong to the identified group, it indicates belonging, safety, security. Confessional statements indicate the boundaries of the faith community, both delineating and protecting the community (cf. confessions as symbols by which the church is distinguished from the world - Schulze, 1991:4-5; Belgic Confession Art. 29). To those 
who do not belong, it is a social boundary marker that excludes them, but also an indirect kind of invitation: this is who we are, join us!

Important for our topic is that creeds were usually formulated in a context of controversy concerning the true meaning of Scripture, so that the teaching of the church could be regulated and so that the church could be guarded against error. This fact gives every one of the creeds a very specific thrust, so that we should guard against over-asking the creeds in our expectation of their missionary role in our churches of today. Whatever missionary prompting they may present, will probably be indirect, coming from the consequences of doctrinal statements not primarily concerned either with mission as such or with the missionary calling of the church (cf. Haak, 1999:61$64,67)$. Some digging will therefore be required. The remarks below represent such digging, from a missionary point of view. Hopefully, the results will inspire some discussion, if not a clear statement of the mission of the church according to the confessions.

\section{The Heidelberg Catechism}

In its origins, the Heidelberg Catechism was only slightly polemic. Its intention was never dispute with opponents (with the possible exception of the contentious Question and Answer 80), but rather religious instruction for the young (cf. Schaff, 1877:531-532). It was written as a summary of the Christian faith from the Word of God. Indeed, in the reformed world, it also functions as a standard of public doctrine, explaining as it does so very clearly the Calvinistic system (Schaff, 1877:540).

\subsection{The foundations and limits of mission}

Although it cannot be said that the famous introduction to the Heidelberg Catechism in Answer 1 had mission in any form in mind, it certainly sets out the constitution for all mission. In its unashamedly exclusive stress on our only comfort in life and death being our belonging to and serving of Jesus Christ, it defines both the foundations and the limits of all mission. The scope of this first answer is breathtaking in its profundity.

It speaks of comfort, thereby recognising the universal human condition of misery, of alienation from all comfort. It recognises the human heart in its pain and in its cry for comfort. At the root of man's misery is the fact that there is nobody he can call father. He is like an abandoned child, alone in a terrifying world. He has to fend for 
himself in a world where our highest effort usually delivers no more than thorns and thistles (Gen. 3:18). He has nobody to defend him in adversity - only his own futile efforts which are so easily overwhelmed by this sad world (cf. 9:26; 103).

This is therefore no sterile doctrinal document: it is a pastoral hand reaching out to the lost and the lonely, the suffering and the crying, those lost in despair and hidden in oppression. If there were a fault, it is not in the Catechism but in the heart that reads it. How can I read and speak of comfort, even confess it, as the only comfort available, but treasure it only for myself? How can I rejoice in liberation from sin and the tyranny of Satan, revelling in the freedom of serving Christ, and yet be blind and deaf to the suffering of the world around me?

The Catechism speaks of belonging to a Saviour both body and soul, thus including total human existence in all its diversity in the desperate need for one Saviour: not one for the body and another for the soul. No, the very same Saviour will be responsible for the redemption of both body and soul (cf. Bavinck, 1954:63-64). Consequently, in whatever way we get involved in the lives of people, we cannot say that we want to save only their souls, while ignoring their plight in terms of poverty, hunger, disease, injustice and oppression, claiming that it is none of our business. Also, inversely, we cannot focus only on the material and bodily life of people, declaring the soul to be respected neutral territory where we dare not influence the sovereign right of the individual to choose for himself. The whole life of man cries out to be comforted, and this first answer points the way. Our cry for comfort, whatever its origins may be and whatever the circumstances causing us to cry out, can only be answered by one Person: Jesus Christ.

The content of our missionary preaching is also pointed out clearly: How is the cry of the human heart for comfort answered?: by the gospel of payment for our sins; by the blood of Jesus; and by his delivering us from the tyranny of the devil (cf. 5:12-8:25). Individual and collective sin, and the tyranny of Satan are the roots of misery and the robbers of God's comforting gifts of grace (4:9).

3 The numbering used in heading 3 and its subparagraphs refers to the relevant Lord's Day: Question and Answer of the Heidelberg Catechism, so that 9:26 refers to Lord's Day 9, Question and Answer 26, following common practice in this regard. 
In this way the Catechism penetrates right through all liberal ecumenical and humanistic probing of the human condition. What is at the root of all human misery? Some people say political injustice, or oppression and violence. Others point to poverty and economic imbalances between North and South. Still others speak of disease and lack of education. However, the Catechism is clear that sin and Satan are at the root of human misery (2:3-4:11). This emphasis of the Heidelberg Catechism makes mission, as gospel teaching, both possible and necessary! All those other things might be the visible manifestations of sin and Satan, but they are not the root cause. Only once this has been accepted, can we go back and, in the name of Jesus, fight for liberation, side by side with the victims of injustice, oppression, poverty, disease and bad education.

Although the Catechism never uses the word conversion at this point, it is clear that it speaks of a total reorientation of human life if its seeks to be comforted. The Catechism is no modern-day respecter of the integrity of the sovereign individual: I am not my own, but I belong body and soul to Jesus Christ, living for him and not for myself, for sin or for Satan. Christ is the magnetic north that realigns all human life according to its creationally intended directions (3:6), thereby bringing it to its created potential and liberating it from all constraints and chafing bonds. The chaos of human life is brought to order in one way only: by the magnetic field of Jesus Christ in his sovereign, loving, saving Lordship (cf. also the exclusive statement of 11:29-30, echoing the words of Acts $4: 12$ ). To be truly free, is to be a slave of Jesus Christ only. 4

The emphasis in 1:1 on the grace of God in Jesus Christ does not in any way detract from the sobriety of the Catechism in terms of the anger of God about human sin and injustice. This, of course, is always the other side of the coin of our missionary preaching; the warning note that tells people that, even if we proclaim the mercy and the love of a saving God, He is not a God to be toyed with: God is not only merciful, but also just. In the words of $4: 10$ (cf. $4: 11$; 19:52; 32:87):

He is terribly angry about the sin we are born with as well as the sins we personally commit. As a just judge He punishes them

4 Cf. in this regard also the explanation of the first commandment in 34:94-95. This commandment can be called the foundation of all mission: there is only one true God, and He must be worshiped with heart and soul by one and all! This emphasis is echoed in 45:117, where the nature of prayer is discussed. 
now and in eternity. He has declared: 'Cursed is everyone who does not continue to do everything written in the Book of the Law'.

This fact makes our mission of reconciliation so much more desperate in its urgency as we cry out to people: "we implore you on Christ's behalf: be reconciled to God!". "We know what it is to fear God, [therefore] we try to persuade men. [...] Christ's love compels us" (2 Cor. 5:20, 11, 14).

\subsection{Our Christian identity}

Perhaps the answer that speaks most directly to the heart of Christians about our task in the world, is to be found in $12: 32$, where our identity as Christians is defined:

Why are you called a Christian?

Because by faith I am a member of Christ and so I share in his anointing. I am anointed to confess his name, to present myself to Him as a living sacrifice of thanks, to strive with a good conscience against sin and the devil in this life, and afterward to reign with Christ over all creation for all eternity.

There is an element of wonderful piety here, which is all too often understood by well-meaning Christians in a pietistic way as being relevant only to the inner life of my individual soul. However, commentaries on the Heidelberg Catechism identify this answer as one of the most missionary in the whole confession (cf. Veldkamp, s.a.:168-172; Spykman, 1984:87-88).

First of all, it is essential to recognise the all important emphasis of this answer. There can be no discussion about my identity or calling as a Christian apart from that very personal, intimate (mystic!) union with Christ. It is this union alone that makes me what I am. It is from the transforming power of this union alone that I speak and confess and witness (cf. John 15:1-5). It is the three-fold office of Christ alone which defines and motivates and makes possible my work in this world, which in this sense remains the work of Christ Himself, done through me. In this sense, we should say that no mission is possible without intimate union with Christ, and also that true union with Christ can have no other effect than missionary activation of believers and churches, for the simple reason that the Christ with whom we are joined in mystic union never stops reaching out to the world. 
From this union with Christ, his anointing as Prophet, Priest and King becomes also my anointing to these same offices. Each of these three offices can be shown to have missionary elements to them:

- Prophet: According to Friedrich (1968:853), prophecy is also proclamation, just like evangelism. Prophecy in the Early Church served to admonish, console, encourage, reveal sin and call to repentance (Friedrich, 1968:848). Although evangelism is as a rule directed to unbelievers, and prophecy to the congregation of believers, Acts 2:17 indicates that even prophecy is sometimes evangelistic in its intent. At this mighty event of Pentecost, the prophecy mentioned by quoting Joel 2:28-32 clearly also included witnessing to, warning and pleading with unbelievers: "Save yourselves from this corrupt generation!" (Acts 2:40). Note also that the young church's mission to the world starts with the anointing of the Spirit, which transforms ordinary men and women into prophets of Jesus Christ and sends them to unbelievers, urging them to repent and turn to God! Confessing the name of Christ (12:32) thereby becomes a prophetic speaking about God's will of salvation: addressing sin directly, calling to repentance, speaking about Christ in a way that will attract people to Him and to the same union with Him that I enjoy.

- Priest: the classic texts about the priesthood of believers are 1 Peter 2:5 and 9. If we compare these verses, we see that offering spiritual sacrifices to God and declaring ("broadcasting" cf. Schniewind, 1964:67) the praises of him who called us out of darkness into his wonderful light are parallel actions, if not one and the same thing. In other words, our liturgical service in the holy presence of God is at the same time directed to the world. It is not for nothing that in the very next verses (1 Peter 2:11-12) Peter continues by calling Christians aliens and strangers who are called to live among pagans in such a way that even these pagans will one day glorify God (cf. Bavinck, 1954:55-56). We find the same idea in 32:86, the introduction to the third main section of the Catechism, concerning our gratitude for salvation: the good works we do serve to win our neighbours for Christ (1 Peter 3:1-2). We are to live missionary lives by the simple act of obedience to the Word of God - this is our spiritual sacrifice to God.

So we see that the offering of our spiritual sacrifices to God, offering our bodies as living sacrifices in spiritual worship (Rom. 12:1), and praising God for our salvation are not acts intended to 
be done in private, hidden away in dark, mysterious, incensefilled sacred spaces, but out in the open, in the world, among the pagans ... with the express intention of bringing them to Christ and to the moment of glorifying God on the day of judgement (cf. Kistemaker, 1987:91-97). This is mission in its essence!

- King: to share in the anointing of Christ means, according to $12: 32$, that I will strive with a good conscience against sin and the devil in this life. Returning again to the Scripture references given by the Catechism, we find the same text of 1 Peter 2 mentioned, but now verse 11: "Dear friends, I urge you, as aliens and strangers in the world, to abstain from sinful desires, which war against the soul." This might seem a very private war, waged in the hidden depths of the heart, but verse 12 shows again that there is a missionary intention even in my private struggle against secret sin: I have to live such a good life among unbelievers that they too will end up glorifying God!

Another reference here is to Ephesians 6:11, where Paul urges believers to put on the full armour of God. Again, this is not merely for a private battle, but for a full-scale war against rulers and authorities, the powers of this dark world and even against the spiritual forces of evil in the heavenly realms (Eph. 6:12). The battle is not merely defensive, but aims to conquer new territory: we are to go out with feat fitted with readiness to proclaim the gospel of peace (Eph. 6:15 - most English translations follow the notion that "readiness" indicates readiness to proclaim or witness 5 - cf. Grundman, 1964:704-706; MacDonald, 2000:345-346;6 Louw \& Nida, 1989:6837 and Oepke, 1967:312), armed with the sword of the Spirit, the Word of God. In the wide definition of the "enemy" in this battle, it is clear that this war can never be fought only in the privacy or our own hearts, but will be waged in the midst of the world, in the lives of people, and on the public stages of our society.

$5 \quad$ Contrary to this interpretation, cf. Floor (1995:206) and Grosheide (1960:96). Neither of these commentators, however, make mention of the obvious parallel of Isaiah 52:7, nor do they consider the semantic implications of readiness (et oimasia), which is readiness for action - action defined as such by the dynamic word eujing gevion. 


\title{
3.3 The church: product of Christ's fellowship-seeking and saving love
}

Now, when we turn to the church, we find that the identity of individual believers is also the identity of the church, and the anointing of individuals to prophets, priests and kings, also implies that the church is a prophetic, priestly, and royal fellowship - doing the same work corporately in its fellowship as its members do individually in their personal spheres of influence.

Especially important here, though, is the quality of the fellowship of the church. As Bavinck says (1954:56-57; translation - JJFK), with reference to Philippians 2:14-15:

\begin{abstract}
All work, regardless of how much we paid for it or how impressive it is in its design, that does not rest in a congregation that has found the secret of mutual love, will prove to be futile. Both mission and evangelism simply cannot do without that one moment of creating jealousy (among onlookers standing outside the church and looking in).
\end{abstract}

Our confession about the church (21:54-55) is once again a poignant expression of trust in Jesus Christ:

I believe that the Son of God through his Spirit and Word, out of the entire human race, from the beginning of the world to its end, gathers, protects, and preserves for Himself a community chosen for eternal life and united in true faith. And of this community I am and always will be a living member.

This simple statement contains a wealth of missionary persepctives. The following points highlight a few of them.

Firstly, we should honour the emphasis of the Heidelberg Catechism by starting with Christ. He works through all ages of history to gather a community of people as his personal possession, for personal fellowship with $\mathrm{Him}$, in order to share his gifts and treasures with those He gathers. Here we see the loving, fellowship-seeking and saving heart of Christ at work as $\mathrm{He}$ is present in the world of comfortless humanity! This is the missio Dei in the Person of Jesus Christ (cf. Bosch, 1991:389-393). One cannot help but hear his cry in Matthew 11:28 - "Come to Me, all you who are weary and burdened, and I will give you rest"!

Secondly, this is the Christ who is present in this world through his chosen people, speaking to the tormented hearts of lost people with the gospel of peace and the words of the ministry of reconciliation 
(2 Cor. 5:18-20; cf. Bavinck, 1954:53), which we should be ready to proclaim. This is the Christ whose fellowship-seeking heart is turned towards the world, seeking and calling the lost, and taking the church with Him in this great saving work. This is why Bavinck $(1954: 70)$ can say so unequivocally that mission is the work of the church, yet at the same time it is the work of Christ Himself through his church (cf. also Bosch, 1991:372, 378-381).

Thirdly, it is not without reason that we confess that Christ gathers his church through his Word and his Spirit. This is the sovereign work of the Lord of all things. Never once is either the initiative or the power in the hands of people, however holy or powerful or rich they might be, for the Word of Christ alone is the saving power of God in the lives of people (Rom. 1:16). There is no one who dares to preach without having been sent by Christ and speaking the words given by Christ (Rom. 10:14-17), and there is no one who can believe without the Spirit of Christ granting faith and changing hearts (1 Cor. 1:10-16). Always we have to say with Paul: "I ..., yet not I but the grace of God ..." (1 Cor. 15:10).8

Fourthly, this is a profound comfort to all involved in the beautiful, yet seemingly impossible work of mission. Many missionaries will attest that they often find themselves heading for seemingly impenetrable walls, not knowing what to do or how to do it. They sometimes see their work dashed to pieces on the rocks of sin and hardened hearts. They see unfortunate circumstances making months of hard work meaningless in one day. They see people in whom they trusted turn away from Christ and following their old ways. Many are the times they ask in despair: What is the meaning of all this? Why do we do this? The answer is: because Christ gathers for Himself a community chosen for eternal life! Again, we have to repeat, always in great humility: "I ... and yet not I ...".

Fifthly, mission is universal. We cannot say that we should focus our missionary work only on the people of the Third World, or only on those who are under oppression, or those who are poor or sick. If we confess with the first few Lord's Days of the Heidelberg Catechism that indeed all people are lost and without comfort, then mission should likewise extend to all people. That is why the inclusion of this phrase is so important: "The Son of God ... out of the entire human race ... gathers ... for Himself a community"! It is given in Noordegraaf (1983). 
high time that the old missionary direction from North to South and from West to East come to an end: in the universal church of Christ, He moves from all to all, excluding no single church.

Sixthly, the end objective of mission is often seen to be the salvation of the individual. Once (a promise of) conversion is achieved, the goal has been reached. However much emphasis the Catechism places on the individual, even addressing the individual throughout, this part of our confession is very clear as to Christ's objective: He is gathering a church, a fellowship of saved people, a community. This fellowship character of the church is seen at its clearest in the sacrament of the Lord's Supper, which shows that we are "flesh of his flesh and bone of his bone" (28:70). Regarding the communion of the saints, 21:55 is very exclusive in its language: believers share in Christ and in all his treasures and gifts "as members of this community"! This is the well-known metaphor of the church as the body of Christ (cf. 1 Cor. 12:12-13), which leads us to conclude that the objective of mission work is the planting of churches (cf. Bavinck, 1954:160-161). Significantly, at the heart of the prayer life of the church is the Lord's prayer, where we ask in the second request: "Let your Kingdom come!" (48:123), which is then explained as follows:

'Your kingdom come' means, [...] Keep your church strong, and add to it ...

Another perspective is offered by $26: 69-27: 74$, which speaks of the sacrament of baptism as the mark of being a member of Christ (26:70) and of being received into the church of Christ (27:74). The two promises concerning baptism, quoted from Scripture in the Catechism, are both taken from a context of mission (Matt. 28:19 and Mark 16:16). Therefore, mission, the sacrament of baptism and the church as the body of and fellowship with Christ are all intimately connected.

\section{The Canons of Dordt}

The Canons of Dordt are the most polemic of the three reformed confessions. As a result of the contra-Arminian objectives of the Canons, we cannot expect a broad and comprehensive approach to all matters doctrinal. Unlike the Heidelberg Catechism, the Canons of Dordt never pretended to present a complete overview of Christian faith as such, but instead narrowed its focus to specific soteriological matters. However, despite this, we find in the Canons 
of Dordt a wonderful view of the loving heart of a God who searches out all who belong to Him and restores them to life as He intended.

\subsection{The loving heart of God seeking salvation for man from eternity to eternity}

Right at the beginning of the Canons of Dordt, under the first main point of doctrine regarding divine election and reprobation, we find a beautiful introduction with a truly evangelical heart (1:1-39): yes, it is true that all people have sinned and have come under the curse of death, thus destroying all comfort for mankind, but the love of God is not satisfied with this. In his mercy, He sends preachers of the joyful gospel of his love in Jesus Christ, so that lost people may be brought to repentance and faith in Christ. God, says 1:7, calls and draws the chosen ones into Christ's fellowship through his Word and Spirit - He finds us, we do not have to search for Him. With infinite patience, but with unstoppable resolve, God continues to fulfil his promise and achieve his objectives, searching out those who belong to Him, cleansing and washing them to perfection through the blood of Christ and the transforming grace of his Word and Spirit (cf. 3/4:11 and 16). Once again, a short but powerful indication of the missio Dei (cf. Bosch, 1991:389-393): God is at work in this world through his Word and his ministers to turn the darkness of the curse into the light of blessing (cf. also Heyns, 1978:93-94, with reference to Barth).

In 1:6-7 we also find the expression of the mysterious link between the visible result of the preaching of the gospel, namely repentance in the hearts of some, and the invisible decision of God to choose some for eternal life and others not (cf. Eph. 1:4, 11). However unpopular this doctrine of divine predestination is, it does provide us with solid bedrock under our feet as we go out into the world to preach the gospel: there will always be fruit; there will always and inevitably be those who turn to God (just as there will always be those who do not - cf. 2:6), regardless of faults in the preaching or the preachers, regardless of circumstances and regardless of initial resistance to the gospel. Even though many years may pass without one single, visible convert, we may still fall back on the certainty that those who have been chosen (in the sense of Eph. 1) will

9 The numbering in heading 4 and subparagraphs refers to the chapter and paragraph numbers of the Canons of Dordt, so that 1:1-3 refers to chapter 1 , paragraphs $1-3$, following common practice in this regard. 
irrevocably come to repentance and faith through the irresistible grace of God (cf. 3/4:12), despite the gates of hell seeking vainly to prevail (2:9). As Van der Merwe has rightly remarked, missionaries cannot make gold, they can only discover with the tools of the Word and their witness the gold that has already been given by God (Van der Merwe, 1960:91; cf. also John 17:6, 9). From the Heidelberg Catechism, we already know that Christ is gathering his church without fail. From the Canons of Dordt, we now know that the end is also guaranteed: all those who have been intended for eternal life, will inherit it. Between these two solid rocks, we are allowed to do our work in peace and assurance as the anointed ones of Christ: prophets, priests and kings in this world in the Name of Christ.

How can we not be inspired by the sight of God moving into this world, seeking out his beloved chosen ones, softening their hardened hearts, breaking down their resistance, with infinite gentleness cleansing and freeing them from the dark mire of sin and death? In fact, this confession is the only one to order us out into the world in no uncertain terms:

This promise, together with the command to repent and believe, ought to be announced and declared without differentiation or discrimination to all nations and people, to whom God in his good pleasure sends the gospel (2:5).

\subsection{The radical corruption of man}

The Canons of Dordt, in reaction to the teachings of the Arminians and Pelagians, are the most outspoken of all three our confessions regarding the total and radical corruption of man. One aspect of this doctrine which has direct bearing on missiological thinking in our time, is to be found in $3 / 4: 4-5$. The Canons clearly teach that there is no possibility of finding, knowing or turning to God simply by means of the light of nature, without the Word and Spirit of God. This is not even possible for those who have the Law of Moses. We read in 3/4:6:

What, therefore, neither the light of nature nor the law can do, God accomplishes by the power of the Holy Spirit, through the Word or the ministry of reconciliation. This is the gospel about the Messiah, through which it has pleased God to save believers, in both the Old and the New Testament.

This accent of the Canons of Dordt cuts off at the root all discussion about the saving potential of other religions and anonymous Christianity (cf. Bosch, 1991:486), and severely limits the possibility of 
serious dialogue with other religions as called for by some in the ecumenical movement. True ecumenicity is only possible within and on the basis of overt fellowship in Jesus Christ (cf. the critical discussion of this topic in Zuidema, 1965:123-158).

This, of course, does not mean that careful, listening conversation with those of other faiths is impossible, or that one should not seek to understand the hearts and minds of people of other faiths (cf. Bosch, 1991:483) from a position of solidarity with the world of sinners (Heyns, 1978:370-372). However, if listening means uncritical acceptance, or the impossibility of appealing to those of other faiths to be reconciled to God through Jesus Christ because $\mathrm{He}$ is the only Way and Truth, we have to draw a line. However deep our solidarity may go with those of other faiths, based on our common humanity, it will always have to be a critical solidarity, based on the exclusivity of the gospel of Jesus Christ (Heyns, 1978:372-374).

On the basis of our confession, we therefore have to deny the possibility that people can approach God along the paths of their own religions, without the revealing and gracious work of God Himself through his Word and Spirit. Perhaps in our time, just as in the time of the Reformation, there should be a renewed emphasis on the unbreakable link between Word and Spirit (cf. Jonker, 1981:50-58) and a strong rejection of natural theology (cf. Van Genderen \& Velema, 1992:126-131), which is often at the root of religious universalism. The Spirit of God works where the Word of Christ is preached, heard and confessed (Van Genderen \& Velema, 1992:112-114).

The universality of mission, which is not restricted in movement from West to non-West and from North to South, seems to be indirectly indicated in $3 / 4: 7$, as discussed under 3.3 above.

\section{The Belgic Confession}

The Belgic Confession was written at a time of fierce religious persecution in the Low Countries, especially under Philip II of Spain, whose reign extended also over the Low Countries. Written by Guido de Brès in 1561, with the help of a few others, it was intended to give an explanation of the reformed faith from the Word of God, especially in order to distinguish reformed Christians from the radical Anabaptists (Schulze, 1991:32). Just like the Heidelberg Catechism, the Belgic Confession is therefore broader in scope than the Canons of Dordt. 


\subsection{The God who seeks fellowship with man in his self- revelation}

In a world where many are seeking God and even more claim to have found Him, while some say that He cannot be known or found at all, the Belgic Confession is characteristically clear in its confessional language: God is there, He is the only God (Art. 1) ${ }^{10}$ and He makes Himself known to man (Art. 2). God's existence as the only God and his self-revelation is one of the strongest missionary motifs in Scripture and in our confessions. This is the foundation of the missio Dei: God comes to man and reveals Himself to us, calling us into fellowship with Him. God's dwelling place and heavenly glory is inaccessible to man, so that the only possibility for knowing God is if He should come to us, in a way that would be accessible to us as sinful, broken humans. It is proof of his grace that God does not come to us in dazzling glory and heavenly splendour that frightens, overwhelms and threatens to destroy us, but that He comes to us in the creation, preservation and government of the universe, in the human language of Scripture and in the humanity of his Son (cf. Heyns, 1992:66).

God's revelation is a fellowship-seeking revelation (cf. Heyns, 1978: 6-7; Van Genderen \& Velema, 1992:39). He never reveals Himself simply for the purpose of factual knowledge, but in order to be known by man ("to know" being used here in the Hebrew sense of the verb ידע). 11 We can therefore, say that He reveals Himself to us in order to draw us into a relationship with Him - even more, into a union with Him in which we can delight in the richness of his love, grace and goodness (cf. Berkhof, 1986:126). This is also the perspective of Article 2, which mentions that God reveals Himself more fully in Scripture for the salvation of his own, meaning for those who belong to Him, who live in fellowship with Him and who therefore have been given life in Him.

In a world where many absolutely refuse to know God (Rom. 1:1820, 23-25), God does not withdraw in indignant silence or hide from

10 The references in 5 and subparagraphs are to the Belgic Confession, e.g. Article/(Art.) 1 refers to Article 1 of the Confession, following common practice.

Cf. the analysis of the noun תעד in Psalm 19:2 by Swanson (2001, par. 1981). 
man. No, He continues to reveal Himself in nature12 and Scripture (breathed by the Spirit), and ultimately in his Son, ${ }^{13}$ to present Himself to man as a gracious, fellowship-seeking God who is willing to lay bare his heart to us in loving vulnerability (cf. Berkhof, 1986:52, 142 - who prefers to speak of "defencelessness") - open to the brutal rejection of those who hate Him.

\subsection{The God who seeks fellowship with man in the incarnation of his Son}

God's vulnerability in seeking out lost mankind is most graphically illustrated in the Person of Jesus Christ, of whom we confess in Article 10 that $\mathrm{He}$ is the exact image of the Father, the true eternal God, the Almighty, whom we invoke, worship and serve. God Himself is so serious about seeking those who belong to $\mathrm{Him}$, that $\mathrm{He}$ was willing to make Himself nothing and take on the nature of a servant, "being made in human likeness" (Phil. 2:6-7; cf. Art.18), becoming a mere man in the person of Jesus. Jesus demonstrated his defenceless vulnerability especially in the ridicule and rejection $\mathrm{He}$ was willing to accept and ultimately in his willingness to die a cursed death on the cross, mocked by the people of Jerusalem and the Romans.14 The incarnation of the Son of God, in which God comes to us in Person as Immanuel (God with us, and also like us in knowing personally our temptations and weakness; Heb. 4:15) and demonstrates to us his caring and saving solidarity with us, therefore becomes the highest revelation of his love for us (Art. 26) and perhaps one of the great cornerstones of mission.

We can now say that God's self-revelation, together with all the means He uses for this purpose (including the incarnation of his Son), constitutes his own mission to the world. God seeks out lost mankind, and calls his scattered children to Himself, as when He came into the garden of Eden and called to Adam and Eve, saying:

12 This does not mean that Art. 2 teaches the possibility of natural theology (cf. 4.2 above). It states clearly that what is needed for our salvation and for the glory of God can only be found in Scripture. Article 7 states this even more clearly.

13 All self-revelation of God is therefore always trinitarian (cf. Art. 8-9).

14 Of course, this is only vulnerability when viewed from the perspective of man. From God's point of view, the qualification of 1 Corinthians 1:17-25 applies, namely what is weak and powerless in the eyes of man, is strong and victorious in the eyes of God. 
"Where are you?" (Gen. 3:9). We confess this in Article 17, where we say:

We believe that our good God, by his marvellous wisdom and goodness, seeing that man had plunged himself in this manner into both physical and spiritual death and made himself completely miserable, set out to find him, though man, trembling all over, was fleeing from Him.

This missio Dei is the only basis of the missio ecclesiae - the mission of the church: we serve God in his fellowship-seeking selfrevelation to the world that does not know Him, but rejects Him as God. It is a humbling task to reflect, as a church and as a Christian, this loving, seeking heart of God in a brutal world where the presence of God is often not only denied but actively resisted.

\subsection{The God who seeks fellowship with man in creation}

God's fellowship-seeking revelation to man is a continuation and reaffirmation of his intentions with the creation of man: man was created for fellowship with God, and creation as such was already an act of fellowship. As Berkhof (1986:157-158) says:

The creative act bears the same stamp as we discovered in the revelation encounter as originating in the very being of God. To create means that God stoops down, that He limits Himself, that He provides living and breathing space for the other ...

This is confessed first in Article 12, where we say that everything was created for its own unique way of serving God. The whole created order was put in place and is now sustained by God through Jesus Christ (cf. Art. 13), for the sake of man, who needs this larger order to be able to serve God himself. Creation and the providence of God (and therefore also all history) are aimed at man as God's servant, who lives in fellowship with and obedience to God, and witness to God's grace and fatherly care for his children. In fact, the very idea that man was created in the image of God already speaks of relationship and fellowship. Berkhof (1986:186) says: "man is apparently a being who is made to encounter God, to respond to his Word. Man is a responding creature".

It is precisely for the sake of this response from the side of man that God returns to fallen man to seek Him out and restore Him in love and grace. In his providential reign over man and all of creation, God does not have to accept the results of the fall as irrevocable, but immediately sets out to redeem his tragically broken and lost crea- 
tion. This story of the missio Dei becomes in the end the story of the missio ecclesiae!

\subsection{The God who seeks fellowship with man in the church}

The Belgic Confession also speaks about the church as the holy congregation or gathering of those who are saved in Christ and who are his subjects. Although the motif of fellowship between Christ and those who belong to Him is not immediately evident in Article 27, the motif of Christ as Lord and believers as his subjects provide adequate material to speak of the church as the sphere of Christ's fellowship with those who confess his name. This fellowship is made evident in the washing by the blood of Christ, in the sanctification and sealing by the Holy Spirit and in the preservation by the Father. The church can therefore be called the sacred environment of the triune God's life-giving and life-preserving fellowship with those who have been saved (cf. Berkhof, 1968:343-349, who speaks of the church as a covenant community of fellowship).

It is in this sense that the beginning words of Article 28 should also be understood - however contentious they might appear to some today:

We believe that since this holy assembly and congregation is the gathering of those who are saved and there is no salvation apart from it, no one ought to withdraw from it, content to be by himself, regardless of his status or condition (emphasis - JJFK).

The church is where Christ exercises his discipline and instruction, where believers are built-up by the gifts of fellow believers. It is the life-giving body of which individuals are both dependent and contributing members. The church, in its separation from the unbelieving world (cf. Art. 28), is also the sign to the world of the kingdom of Christ as the alternative and inevitably approaching reality of the end-time (cf. Heyns, 1977:23-29; Bosch, 1991:374377). However, this last emphasis is not found in the Belgic Confession, which does not indicate the task of the church towards the unbelieving world. Still, the necessity of the church and church planting as the result of mission must be emphasised (cf. 3.3 above): Where there is faith, there will be the fellowship of faith - the church. Bosch (1991:372) quotes Braaten (1977:55) when saying: "a church without mission or a mission without the church are both contradictions. Such things do exist, but only as pseudo-structures".

This brings us to Article 29, which deals with the marks of the true church, Here a slightly critical question should be asked. Reading 
this article in the light of the circumstances and events giving rise to the Belgic Confession (especially the polemic against the Roman Catholic Church and the Anabaptists), it is understandable that the formulation is as it is. However, it could be asked whether this is all that can be said concerning the marks of a true church. What seems to be missing is that vital aspect of the missionary heart of the church, which belongs to the very being of the church (based on 1 Peter 2:9, already discussed above; cf. also Bosch, 1991:372): as God is a missionary God, his church is a missionary church. Of course, it then becomes a point of discussion whether a church which is not active in mission can be called a false church! There are a number of possible solutions to this problem:

- It could be argued that mission is implied in holding to the pure Word of God in all respects. True preaching of the Word will always include calling people to repentance, on the basis of God's revealed love in Jesus Christ. Baptism as sacrament in itself also constitutes a boundary of the true church, bringing people into the fellowship of the church and Christ. Holy Communion as sacrament is at its heart a celebration of the fellowship-seeking heart of God, who not only seeks but also provides that fellowship through the body and blood of his Son. Finally, discipline is also a means to safeguard the identity of the church, preventing her from becoming so much like the world that she loses her own, distinctive and witnessing identity in the world.

- Heyns (1977:110-111) attempts to extend the first mark of the true church, the pure preaching of the gospel, to include missionary preaching to the world, and remarks that the church which does not do this thereby denies its own calling and right to exist (thus effectively calling mission the raison d'être of the church).

- Bosch (1991:373), however, is more convincing in his solution that a missionary church is not always and overtly involved in missionary projects. Its missionary dimension can also be revealed in the way it welcomes strangers to its regular services, in the way its members participate in the ministry of their church and are equipped for their service in society. However, a missionary church will also be involved with society and move beyond its own walls. 


\section{Conclusion}

From the above, it is clear that the reformed confessions do not deserve to be called either an embarrassment to the church, or a stumbling block in the way of a church seeking to find and activate its missionary calling. However, it is also clear that the missionary implications of our confessions are mostly hidden gold, which will not be found through superficial and half-hearted digging. It is there to be discovered, but it will require some serious effort. Maybe what is needed now is a document offering a clear exposition of the missionary calling of the church on the basis of the confessions.

Perhaps the greater embarrassment for the church should be the fact that the historic confessions have become largely forgotten and that the church itself is no longer a confessing church. Without the urge to declare publicly and intentionally the praises of Him who called us out of darkness into his wonderful light, neither the confessions we have nor the ones that might still be written will change anything in our missionary inactivity. It is not what we have (or don't have) on paper that should be of concern, but what we have written in our hearts!

\section{List of references}

BAVINCK, J.H. 1954. Inleiding in de zendingswetenschap. Kampen: Kok.

BELGIC CONFESSION. http://www.gksa.co.za Date of access: 18 Feb. 2006.

BERKHOF, H. 1986. Christian faith: an introduction to the study of the faith. Grand Rapids: Eerdmans.

BOSCH, D.J. 1991. Transforming mission: paradigm shifts in theology of mission. Maryknoll: Orbis.

BRAATEN, C.E. 1977. The flaming center. Philadelphia: Fortress.

CANONS OF DORDT. http://www.gksa.co.za Date of access: 19 Feb. 2006.

FLOOR, L. 1995. Efeziërs: één in Christus. Kampen: Kok. (Commentaar op het Nieuwe Testament, derde serie.)

FRIEDRICH, G. 1968. prof hth $\sim$ ktl. Theological Dictionary of the New Testament, 6:781-861.

GROSHEIDE, F.W. 1960. De Brief van Paulus aan de Efeziërs. Kampen: Kok. (Commentaar op het Nieuwe Testament.)

GRUNDMANN, W. 1964. ełloimo , ef oimazw, ef oimasia, proet oimazw. Theological Dictionary of the New Testament, 2:704-706.

HAAK, C.J. 1999. Kerk in de 21e eeuw: weer kerk voor de wereld zijn. Kampen: Voorhoeve.

HEIDELBERG CATHECHISM. http://www.gksa.co.za Date of access: 18 Feb. 2006.

HEYNS, J.A. 1977. Die kerk. Pretoria: NG Kerkboekhandel.

HEYNS, J.A. 1978. Dogmatiek. Pretoria: NG Kerkboekhandel.

HEYNS, J.A. 1992. Inleiding tot die dogmatiek aan die hand van die Nederlandse Geloofsbelydenis. Pretoria: NG Kerkboekhandel. 
JONKER, W.D. 1981. Die Gees van Christus. Pretoria: NG Kerkboekhandel.

KISTEMAKER, S.J. 1987. Peter and Jude. Welwyn: Evangelical Press. (New Testament commentary.)

LOUW, J.P. \& NIDA, E.A. 1989. Greek-English Lexicon of the New Testament based on Semantic Domains. Vol. 1. Cape Town: Bible Society of South Africa.

MACDONALD, M.Y. 2000. Colossians, Ephesians. Collegeville: Liturgical Press. (Sacra Pagina, 17.)

NOORDEGRAAF, A. 1983. Creatura Verbi: de groei van de gemeente volgens de Handelingen der Apostelen. 's-Gravenhage: Boekencentrum.

OEPKE, A. 1967. opl on ktl. Theological Dictionary of the New Testament, 5:292-315.

SCHAFF, P. 1877. The creeds of Christendom with a history and critical notes. Vol. 1: The history of the creeds. http://www.ccel.org/ccel/schaff/creeds1.html Date of access: 28 Feb. 2006.

SCHNIEWIND, J. 1964. aggel i ktl. Theological Dictionary of the New Testament, 1:56-73.

SCHULZE, L.F. 1991. Ons glo met die hart. Orkney: EFJS.

SPYKMAN, G.J. 1984. Never on your own: a course of study on the Heidelberg Catechism and Compendium. Grand Rapids: Board of Publications of the Christian Reformed Church.

SWANSON, J. 2001. Languages: Hebrew (Old Testament). Logos Research Systems: Logos Bible Software. (Scholar's edition.)

VAN DER MERWE, D.C.S. 1960. Sending en uitverkiesing. Potchefstroom: PU vir CHO. (Unpublished Th.M. thesis.)

VAN GENDEREN, J. \& VELEMA, W.H. 1992. Beknopte Gereformeerde dogmatiek. Kampen: Kok.

VELDKAMP, H. s.a. Zondagskinderen: kanttekeningen bij de Heidelbergse Catechismus. Deel 1. Franeker: Wever.

ZUIDEMA, S.U. 1965. De Christus der Schriften en oecumenische theologie. Amsterdam: Buijten \& Schipperheijn.

\section{Key concepts:}

Christian identity

church planting: goal of mission

mission

missionary church

reformed confessions

\section{Kernbegrippe:}

Christelike identiteit

gereformeerde belydenisskrifte

kerkplanting: doel van sending

missionêre kerk

sending 